
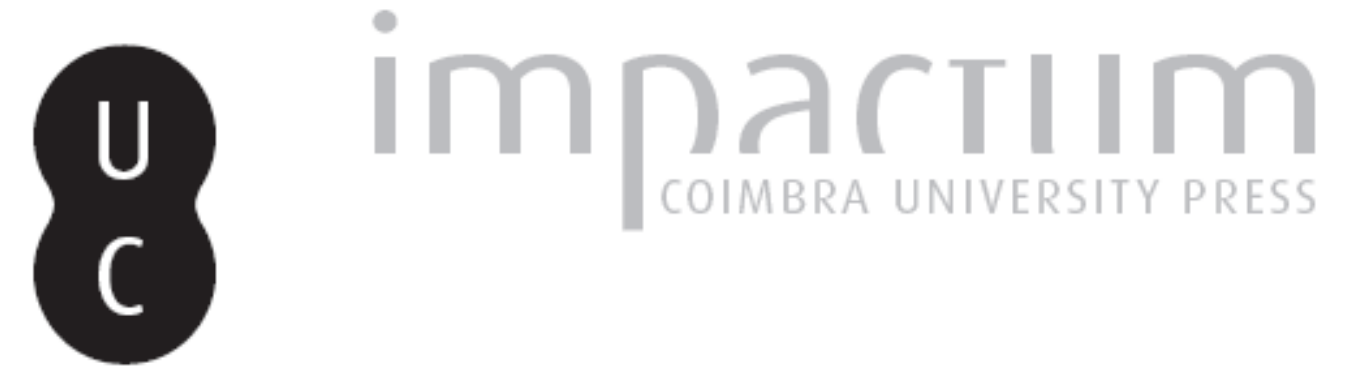

\title{
Considerações sobre a estética de um poeta pessimista
}

Autor(es): $\quad$ Ribeiro, António Camilo

Publicado por: Imprensa da Universidade de Coimbra

URL persistente:

URI:http://hdl.handle.net/10316.2/43743

DOI: $\quad$ DOI:https://doi.org/10.14195/2183-8925_13_6

Accessed : $\quad$ 26-Apr-2023 15:33:42

A navegação consulta e descarregamento dos títulos inseridos nas Bibliotecas Digitais UC Digitalis, UC Pombalina e UC Impactum, pressupõem a aceitação plena e sem reservas dos Termos e Condições de Uso destas Bibliotecas Digitais, disponíveis em https://digitalis.uc.pt/pt-pt/termos.

Conforme exposto nos referidos Termos e Condições de Uso, o descarregamento de títulos de acesso restrito requer uma licença válida de autorização devendo o utilizador aceder ao(s) documento(s) a partir de um endereço de IP da instituição detentora da supramencionada licença.

Ao utilizador é apenas permitido o descarregamento para uso pessoal, pelo que o emprego do(s) título(s) descarregado(s) para outro fim, designadamente comercial, carece de autorização do respetivo autor ou editor da obra.

Na medida em que todas as obras da UC Digitalis se encontram protegidas pelo Código do Direito de Autor e Direitos Conexos e demais legislação aplicável, toda a cópia, parcial ou total, deste documento, nos casos em que é legalmente admitida, deverá conter ou fazer-se acompanhar por este aviso.




REVISTA DE HISTÓRIA DAS IDEIAS 13

\section{Antero de Quental}

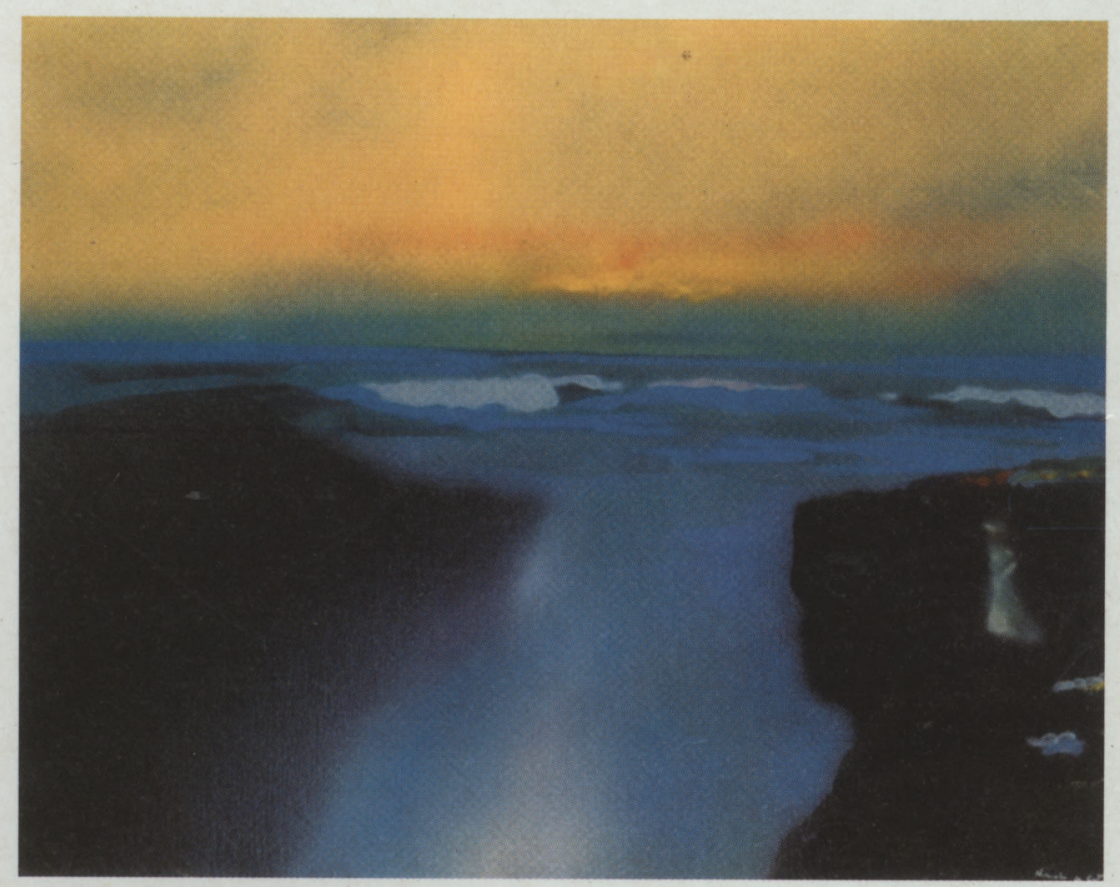

INSTITUTO DE HISTÓRIA E TEORIA DAS IDEIAS FACULDADE DE LETRAS

COIMBRA 1991 


\section{CONSIDERAÇÕES SOBRE A ESTÉTICA DE UM POETA PESSIMISTA}

- Que te diz a natureza, A despedir-se saudosa

Já do dia?

Quando a noite é mais formosa E o luar tem mais beleza?

$$
\left.-F \text { sia... ( }{ }^{1}\right)
$$

Da obra de Antero de Quental é na poesia que mais concretamente se destaca não só uma natureza artística mas também uma evolução psicológica. É na sucessiva produção da obra poética que se nota a transição do canto fervoroso, apaixonado, juvenil, das Odes Modernas, para a linguagem plena de subjectividade e de metafísica dos Sonetos.

Ainda que variando de substância a poesia de Antero mantém-se sempre, no essencial, idêntica, reflectindo os princípios que o artista entendia que toda a poesia exige, isto é: ser moral (por oposição a imoral ou a amoral), verdadeira, estar unida ao sentimento, racional; ser, sempre que possível, uma poesia do seu tempo e, por conseguinte, social, revolucionária em caso de necessidade. Deve ter por telão de

* Instituto de Educação da Universidade do Minho.

(') "A...", in Raios de Extinta Luz e outras Poesias, pp. 31-32. 


\section{Antero de Quental}

fundo a natureza. Todavia, se Antero frisa a união que o verdadeiro poeta deve manter com a natureza nunca se apresenta como um naturalista. A questão é outra: a poesia encontra-se ligada à natureza por tradição (na poesia greco-latina, nos poetas do Renascimento): assim, a sua posição e a da constatação de uma correspondência histórica e não de empenho pessoal ou de escola. A poesia deve ser, além disso, realista e filosofica - di-lo em período posterior do seu pensamento.

Há uma outra constante: a sua presença. Todo o canto do poeta é o desafogo do que se lhe passa na alma. Neste aspecto, o que escreve são confissões de carácter profundamente humano, que nos tocam, nas quais o homem se manifesta e desvenda aos demais. Não é de admirar, portanto, que as qualidades que julga próprias de todo o verdadeiro poeta - pureza, independência, idealismo, sentimento, sensibilidade, dom profético - sejam precisamente aquelas que os biógrafos lhe atribuem. Antero poeta concebe a imagem do verdadeiro poeta a semelhança da sua.

Não obstante, a poesia de Anteró de valor variável e, nem sempre, de primeira qualidade - confirma-no-lo a voz autorizada de Guerra Junqueiro ( ${ }^{2}$ ). Particular relevância merecem, nesta perspectiva, os Sonetos, de majestade superior e inalcançável transcendência. Os Sonetos nãosão, somente, a manifestação duma sensibilidade e lucidez suprema mas também a expressão própria e particular que essa sensibilidade encerra. As prosas, os ensaios, são o produto do estudo e da reflexão. Mas não provocam a mesma emoção nem a mesma impressão. $O$ que equivale a dizer que o melhor da sua obra se deve procurar na poesia e que para além de conferencista, polemista, político, panfletário, di vulgador, filósofo, esteta, Antero foi, sobretudo, poeta. Poeta pela aptidão que tinha para pôr o pensamento em verso (sendo a facilidade a primeira das condições do talento); poeta pela maior facilidade para expor em verso que em prosa - o verso era sempre o primeiro apoio, como confessou; poeta, ainda, pela verdade do sentimento. Transparece que se trata de uma poesia sentida, a confissão mais íntima a que pode chegar um espírito enquanto testemunho da verdade.

Nãoé este o momento adequado para desenrolar outras considerações

(2) "O Drama da sua Vida", in Anthero de Quental. In Memoriam, p. 475. 
justificativas da profunda essência poética dos Sonetos. Parece visível a transcendência, a doçura, a fantasia, o tormento que contêm. Pode criticar-se a matéria metafísica e psicológica de alguns ou o transporte declamatório de outros. Mas sente-se que neles se encontra a verdadeira poesia.

Se acreditarmos sem reticências que, para Antero, versejar foi sempre coisa perfeitamente involuntária, já surpreendente é verificar que foi um dom que se the esgotou ou que deixou de ter a permanência e a continuidade de outrora. Em 1884, com 42 anos, confessaria que havia três anos que deixara de fazer versos, curiosamente "(...) quando começava a pensar e a sentir algo que realmente merecesse ser posto em verso" ( $\left.{ }^{3}\right)$. E a menos de dez meses da sua morte num momento de depressão, escreveria: "Versos já não os faço..." ${ }^{4}$ ) crendo que a única coisa que ganhou foi fazê-los sempre perfeitamente sinceros....

Dos três géneros clássicos - trágico, épico e lírico - é para este último que se inclina. O lirismo traduz-se numa linguagem de iniciados que deve ser a expressão fiel da vida íntima, dos sentimentos e das paixões individuais $\left({ }^{5}\right)$ sendo que o soneto é para si a forma superior do lirismo, e mais: a sua forma completa, já que é a forma que melhor se lhe adapta $\left({ }^{6}\right)$.

É devido à necessidade de fidelidade ao sentimento que Antero mostrou sempre hostilidade à poesia dos séculos XVII e XVIII, quer dizer, à produção de qualquer tipo de poesia a que faltasse a verdade poética. Por outro lado, desta sua conviç̧ão da identidade da poesia com a moral e com a virtude, a que já nos referimos, resulta a ousada rejeição do Satanismo não obstante o reconhecimento desta nova corrente poética. Para Antero, o satanismo é a expressão de uma consciência, a consciência do homem moderno que reflecte sobre a podridão das suas abomináveis baixezas.

As razões da recusa da poesia satânica, por viciosa e contrária à verdadeira poesia são, provavelmente, de índole idêntica às que conduzem à sua confessa incapacidade para a poesia erótica: "dans le genre érotique je ne crois avoir jamais rien fait qui mérite d'être

( $\left.{ }^{3}\right)$ Cartas de Antero de Quental, a D. Maria Amália V. de Carvalho, 24-12-?

( ${ }^{4}$ Idem, a Alberto Osório de Castro, 25-11-1890.

(5) "A propósito d'um Poeta", in Prosas, Vol. I, p. 98.

(6) "A João de Deus", in Idem, Vol. I, pp. 128-129. 
traduit..." ( $)$. As produções da sua musa erótica "vraiment n'ont rien d'original ni de piquant" $\left({ }^{8}\right)$.

A finalizar. Habituados como estamos a interpretações que dão como pessimista parte essencial da poesia anteriana, facilmente a qualificamos de obscura, nocturna. Inconscientemente, damos cor ao sentimento, associando pessimismo e trevas, tal como associamos pureza e inocência com a alva brancura. De facto, atendemos pouco às exigências que Antero faz à poesia para que esta mereça o título de genuína - ser moral, verdadeira, racional - que, recordemo-lo, são as característicasingénitas da sua. Ora, moralidade, verdadee racionalidade conformam definitivamente em toda a consciência ética (quem o duvida?) o espírito cristalino; não deverão igualmente fundamentar toda a poesia luminosa? O que explica, desde logo, a oposição do poeta à poesia satânica que ele pressente perversa na congeminação e tenebrosa na substância. Desta maneira, se a poesia de Anteroé, bastas vezes, sombria na confabulação nada tem de sombrio o espírito que a concebeu.

Esse ê luz que, ainda hoje, ilumina quem o lê.

(7) Cartas de Antero de Quental, a Tommazzo Canizarro, 10-1-1885.

$\left({ }^{8}\right)$ Ibidem. 